\title{
Willful Blindness and Dishonesty
}

\author{
Sergio Da Silva ${ }^{*}$, Raul Matsushita ${ }^{2}$, Thayana Gonçalves ${ }^{1}$ \\ ${ }^{1}$ Department of Economics, Federal University of Santa Catarina, Florianopolis, Brazil \\ ${ }^{2}$ Department of Statistics, University of Brasilia, Brasilia, Brazil \\ Email: * professorsergiodasilva@gmail.com
}

How to cite this paper: Da Silva, S., Matsushita, R. and Gonçalves, T. (2019) Willful Blindness and Dishonesty. Open Access Library Journal, 6: e5953. https://doi.org/10.4236/oalib.1105953

Received: November 25, 2019

Accepted: December 9, 2019

Published: December 12, 2019

Copyright (C) 2019 by author(s) and Open Access Library Inc.

This work is licensed under the Creative Commons Attribution International License (CC BY 4.0).

http://creativecommons.org/licenses/by/4.0/

\begin{abstract}
Willful blindness refers to situations where people choose not to look or not to question. We investigate the relationship between willful blindness and honesty using a sample of random participants to respond to two questionnaires. We contrast the responses reported with the intrinsic dishonesty of the group (the extent to which people lie when they are assured they cannot be caught). To measure intrinsic honesty, we conduct a die-in-a-cup task. Then, we build indices of perceived honesty and willful blindness that take into account intrinsic honesty. After comparing the indices, we find an inverse correlation between willful blindness and honesty. Thus, our sample suggests we cannot dismiss that those who exhibit more willful blindness are also more dishonest.
\end{abstract}

\section{Subject Areas}

Experimental Economics

\section{Keywords}

Willful Blindness, Honesty, Die-in-a-Cup Task, Intrinsic Honesty, Perceived Honesty

\section{Introduction}

Deceit and self-deception are ubiquitous in both animal and human groups [1]. Though people like to think of themselves as honest, dishonesty pays. Thus, people may behave dishonestly enough to profit, but honestly enough to delude themselves of their own integrity [2]. Therefore, the degree of lying depends on the extent to which self-justifications are available [3]. Cheating and intrinsic dishonesty-that is, the extent to which people lie when they are assured they cannot be caught-are contextually dependent [4] [5]. Here, we focus on one 
particular context influencing honesty: willful blindness [6]. Willful blindness refers to situations where people choose not to look or not to question. However, people are responsible if they could have known, and should have known, something which instead they tried not to see [6]. Willful blindness can ruin private lives and bring down corporations [6]. It is not straightforward to equate willful blindness to dishonesty because not every situation is black and white with a clear-cut "ethical" answer. For this reason, here we investigate whether people who exhibit more willful blindness are also more dishonest.

We consider a die-in-a-cup task [7] to measure the intrinsic honesty of a group of volunteers, described in Section 2. Then, we apply questionnaires to assess the participants' perception of honesty and willful blindness, and investigate the relationship between both.

\section{Materials and Methods}

We randomly recruited 101 volunteers from Florianopolis, southern Brazil. We identified each participant's gender (male or female) and asked them their age (whether above 25 or not). We ended up with 48 females and 53 males; 72 participants ages 25 and older, and 29 participants aged below 25 (mean age $=25.8$; female mean age $=26.3$; male mean age $=25.3$ ). We first applied the die-in-a-cup task to acquaint the degree of intrinsic honesty of the group of participants as a whole. The result of this task was considered as a benchmark in our analysis to contrast it with individual perceptions of honesty, which were evaluated subsequently through a 10 -item questionnaire. Finally, participants were asked to rate five-case vignettes about willful blindness. The responses were given in no more than five minutes on average, and the dataset is available at Figshare (https://doi.org/10.6084/m9.figshare.7571033.v1).

In the die-in-a-cup task, the experimenter (T.G.) asked the participants to roll a die twice, and report the first roll. They received a Brazilian real ( $R$ \$) if they reported a one, two if they reported two, and so on. However, a six earned them nothing. The experimenter could not see the results, and money was paid based entirely on what one participant said. The participants could then lie because it was clear they could not be caught. So we were measuring the intrinsic honesty of our sample of participants as a group. If everyone was being honest, the average claim would be $\mathrm{R} \$ 2.50$. If everyone was maximally dishonest, it would be $\mathrm{R} \$ 5$. If the participants reported the higher of the two rolls, rather than the first one, they were still cheating by bending the rules rather than glaringly ignoring them. After all, lying depends on the available self-justifications, as observed [3]. In such a situation of "justified dishonesty," the expected average payoff is R $\$ 3.47$.

As for the questions of perceived honesty, participants were asked to rate as either "honest," "dishonest," or "very dishonest" each one of the ten statements below (they were also allowed not the respond a question if they so wished):

1) Diverting millions of public money destined to public school meals

2) Using front companies for money laundering 
3) Evading taxes

4) Bribing a police officer not to issue a ticket

5) Favoring relatives or friends using power or influence

6) Cutting in the line

7) Legally finding a way to escape paying taxes

8) Using a disabled parking permit for 10 minutes

9) Unduly keeping $\$ 2$ in change

10) Forging a student I.D. card

To gauge the degree of willful blindness of the participants we exposed them to five situations (some of them real) and asked their verdict.

Situation 1. Let's say your best friend got a lot of sound equipment for a significantly below-market value. In addition to a lower price, the seller did not provide an invoice for the product. Then, your friend decided to sell the goods, but he was intercepted by policemen who discover that they were stolen. Your friend claimed that he had no idea of the illicit origin of the products and that he did not even know the seller. In this case you would consider that your friend is:

( ) not guilty ( ) a little bit guilty ( ) very guilty ( ) I'd rather not answer

Situation 2. Imagine that you need to sell your property because you have to pay for an expensive emergency surgery. Your good is valued at $\mathrm{R} \$ 200,000$. One of the most interested buyers is a famous drug dealer who offers you to pay cash in full. If you will opt to sell the property, how guilty would you feel?

( ) not guilty ( ) a little bit guilty ( ) very guilty ( ) I'd rather not answer

Situation 3. In August 2005, a gang took more than R\$ 164.7 million in a robbery of the Central Bank of Brazil in Fortaleza. The next day, the criminals bought 11 vehicles at a dealership totaling approximately $\mathrm{R} \$ 1$ million and paid in cash. In 2007, the owners of this car dealership were judged for not being suspicious of the illicit origin of the money. How guilty do you think the owners are in this case?

( ) not guilty ( ) a little bit guilty ( ) very guilty ( ) I'd rather not answer

Situation 4. Eduardo, a 25-year-old man, had just been robbed in Mexico. With no money to go back home to Brazil, he agrees to drive a vehicle across the border in exchange for 500 U.S. dollars offered by a group of suspected young men. Halfway down the road, he is approached by police officers who discover that the car contains more than 100 kilos of hidden drugs. Eduardo was arrested on drug charges. How guilty do you think he is? ( ) not guilty ( ) a little bit guilty ( ) very guilty ( ) I'd rather not answer

Situation 5. Alberto owns a guesthouse and is being accused of allowing illegal gambling at his premises. The defendant affirms that he had no knowledge of such illicit activity that had been taking place in his establishment. 
In the face of this, he reinforces his innocence by stating that such knowledge would be essential for the penal relevance of the action. You believe Alberto is:

( ) not guilty ( ) a little bit guilty ( ) very guilty ( ) I'd rather not answer

From the 101 participants, 21 failed to respond to all questions. For the remaining 80 respondents, Cronbach's alpha for the 10-item perceived honesty questionnaire was 0.84 , thus suggesting such items present good internal consistency (or perhaps that they are redundant). Cronbach's alpha for the five-item willful blindness vignettes was 0.61 . If this is lengthened by a factor of two (thus rendering a questionnaire with 10 items), Cronbach's alpha jumps to 0.76 .

\section{Analysis and Result}

As for the intrinsic honesty of the group, the mean of the first roll in the die-in-a-cup task reported by the 80 participants with complete data was 3.5 and the standard deviation was 1.51 . Although the mean is above the threshold of justified dishonesty, that is, 3.47 , there is no statistical difference between the two values ( $p$-value $=0.86$ ). Thus, the group as a whole cannot be considered as very dishonest because the value 3.5 is well below the threshold of maximal dishonesty, that is, 5 . Our finding is not at odds with those in the benchmark study of Fischbacher \& Follmi-Heusi [7], who find in their experiment that not all dishonest participants lie to the fullest extent: a high share of participants reports a 4; only about 20 percent of the participants lie to the fullest extent possible, while 39 percent are fully honest.

The questionnaire of perceived honesty is composed of $10 \mathrm{items,}$ each of them with three possible responses: "honest," "dishonest," or "very dishonest." And the questionnaire of willful blindness has five items, each of them allowing three responses: "not guilty," "a little bit guilty," or "very guilty." Thus, let $H_{i}$ be a perceived honesty index given by

$$
H_{i}=\sum_{k=1}^{10} h_{i k},
$$

where $h_{i k}$ is the response of participant $i$ to the $k$-th item of the questionnaire. Similarly, a willful blindness index $B_{i}$ is defined as

$$
B_{i}=\sum_{k=1}^{5} b_{i k} \text {, }
$$

where $b_{i}$ is the response of participant $i$ to the $k$-th item.

To consider the intrinsic honesty of the group as a whole as a reference, let $R_{i}$ be the result of the first roll for participant $i$. Thus, the remainder of the division $r_{i}=R_{i} / 6$ gauges the payoff in Brazilian real (R\$) earned by each participant. Therefore, we expect a negative correlation between $r_{i}$ and $H_{i}$ because the rolls of the less honest participants lead to higher payoffs.

After taking the weighted scores $h$ as "honest $=3$," "dishonest $=2$ " and "very dishonest $=1$," we found a negative linear correlation between the total scores on the 10-item scale $(H)$ and the values from the die-in-a-cup task (that is, 
-0.18 ). Then, we assigned the scores $b$ as "not guilty $=1$," "a little bit guilty $=2$," and "very guilty $=3$," and found a correlation of 0.11 between the willful blindness index $B$ and the values from the die-in-a-cup task.

Figure 1 shows the dispersion between the indices of perceived honesty and willful blindness. The solid red line is the conditional mean curve $H \mid B$ obtained by local polynomial regression through the non-parametric LOESS method. The correlation between willful blindness and perceived honesty was -0.326 ( $p$-value $=0.003$ ). So our sample suggests we cannot dismiss that participants who show more willful blindness are also more dishonest. Table 1 summarizes the participants' scores related to the three tasks.

\section{Conclusion}

We investigate the relationship between willful blindness and honesty using a sample of random participants who perform a die-in-a-cup task and respond to two questionnaires. We contrast the responses reported with the intrinsic honesty of the group of participants, as measured by the die rolls. Intrinsic dishonesty refers to the extent to which people lie when they are assured they cannot be caught. Then, we build indices of perceived honesty and willful blindness that take into account intrinsic honesty. After comparing the indices, we find an

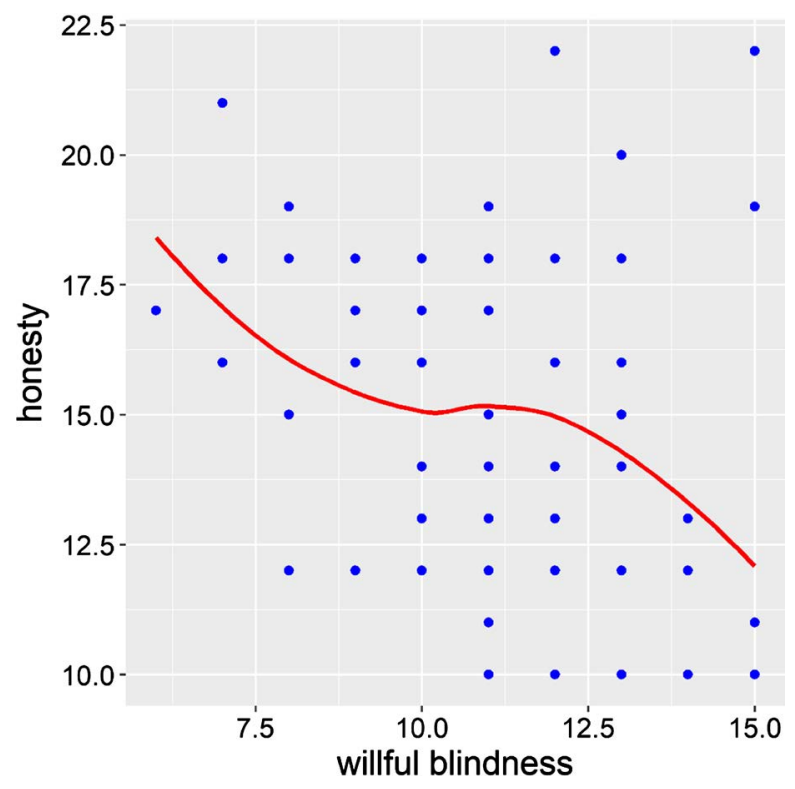

Figure 1. Negative correlation between the indices of willful blindness and honesty.

Table 1. Participants' scores.

\begin{tabular}{cccc}
\hline & Mean & Std dev & $95 \%$ confidence interval \\
\hline First roll in the die-in-a-cup task & 3.5 & 1.51 & $(3.16,3.86)$ \\
Money claimed & 2.83 & 1.58 & $(2.47,3.18)$ \\
Perceived honesty index & 14.7 & 3.37 & $(13.9,15.4)$ \\
Willful blindness index & 11.2 & 2.17 & $(10.5,12.0)$ \\
\hline
\end{tabular}


inverse correlation between willful blindness and honesty. So our sample suggests we cannot dismiss that those who show more willful blindness are also more dishonest.

\section{Acknowledgements}

Financial support from CNPq, Capes and FAPDF is acknowledged.

\section{Disclosure Statement}

The authors declare no competing interests.

\section{Ethical Committee Approval}

This experiment is part of a larger project that is registered at Plataforma Brasil (Comissão Nacional de Ética em Pesquisa) under No. 64758617.2.0000.0121.

\section{Conflicts of Interest}

The authors declare no conflicts of interest regarding the publication of this paper.

\section{References}

[1] Trivers, R. (2011) The Folly of Fools: The Logic of Deceit and Self-Deception in Human Life. Basic Books, New York.

[2] Mazar, N., Amir, O. and Ariely, D. (2008) The Dishonesty of Honest People: A Theory of Self-Concept Maintenance. Journal of Marketing Research, 45, 633-644. https://doi.org/10.1509/jmkr.45.6.633

[3] Shalvi, S., Dana, J., Handgraaf, M.J.J. and De Dreu, C.K.W. (2011) Justified Ethicality: Observing Desired Counterfactuals Modifies Ethical Perceptions and Behavior. Organizational Behavior and Human Decision Processes, 115, 181-190. https://doi.org/10.1016/j.obhdp.2011.02.001

[4] Gachter, S. and Schulz, J.F. (2016) Intrinsic Honesty and the Prevalence of Rule Violations across Societies. Nature, 531, 496-499. https://doi.org/10.1038/nature17160

[5] Herrmann, B., Thoni, C. and Gachter, S. (2008) Antisocial Punishment across Societies. Science, 319, 1362-1367. https://doi.org/10.1126/science.1153808

[6] Heffernan, M. (2011) Willful Blindness: Why We Ignore the Obvious at Our Peril. Bloomsbury, New York.

[7] Fischbacher, U. and Follmi-Heusi, F. (2013) Lies in Disguise: An Experimental Study on Cheating. Journal of the European Economic Association, 11, 525-547. https://doi.org/10.1111/jeea.12014 